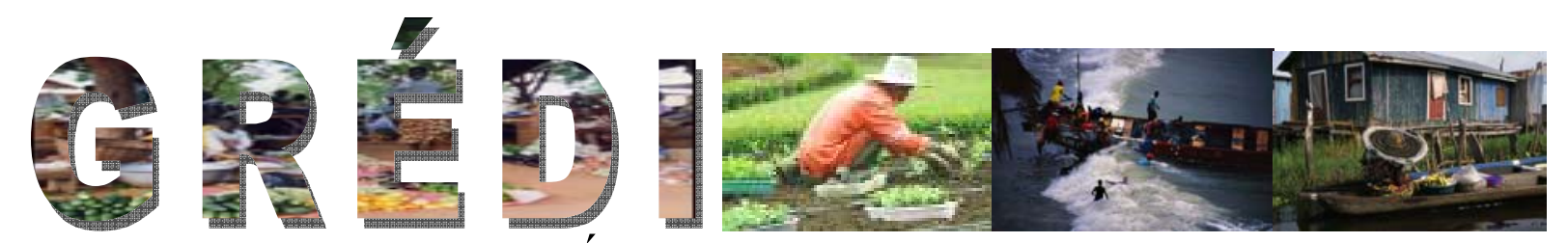

Groupe de Recherche en Économie et Développement International

Cahier de recherche / Working Paper

08-03

\title{
IMPACT OF INFRASTRUCTURE SPENDING IN SUB-SAHARAN AFRICA CGE MODELING APPROACH
}

\author{
Antonio Estache \\ Jean-François Perrault
}

Luc Savard 


\title{
IMPACT OF INFRASTRUCTURE SPENDING IN SUB-SAHARAN AFRICA C G E M O D E L I N G A P P R OACH
}

\author{
Antonio Estache , Jean-François Perrault ${ }^{\Upsilon}$ and Luc Savard ${ }^{*}$
}

Mai 2008

\begin{abstract}
In this paper we construct an archetype CGE model and apply it to six sub-Saharan African countries to explore the impact of scaling up infrastructure in African countries. As part of the debate on the importance of scaling up infrastructure to stimulate growth and provide a push to African economies, some analysts have raised concerns on providing massive financing for the construction of these infrastructures as the process can create major distortion in the economies and have a negative impact by creating Dutch disease symptoms (Adam and Bevan 2006). This study aims to provide some insight into this debate. It draws from the infrastructure productivity literature to postulate positive productive externalities of new infrastructure and Fay and Yepes (2003) for operating cost associated with new infrastructure. We compare various infrastructure investment funded with different fiscal tools. These investments scenarios are compared to non productive investment that can be interpreted as a business as usual scenario. Our results show that increase in infrastructure investment does produce slight Dutch disease effects but the negative impacts are strongly dependent on the type of investments performed and type of financing scheme used. Moreover, the growth effects we introduced contribute to attenuate the negative effects.
\end{abstract}

\footnotetext{
- ECARES, Université Libre de Bruxelles, World Bank

${ }^{\Upsilon}$ International Monetary Fund

* Professor, GREDI, Université de Sherbrooke : luc.savard@,usherbrooke.ca
} 


\section{Introduction}

In light of the large potential increase in Sub-Saharan African infrastructure financing by donors, this proposed work looks at the scope for such financing to be fiscally sustainable. The immediate priority of this work is to feed into the flagship study of Africa's infrastructure by highlighting the extent to which infrastructure investment choices are compatible (or not) with an objective of fiscal sustainability. A computable general equilibrium (CGE) approach is used to compare the impact of increase infrastructure spending in one African country, namely Mali. Recent studies (Gupta et al (2006), Foster and Killick (2006), Mckinley (2005)) have suggested that scaling up aid in Africa will have negative macroeconomic consequences among which the spreading of the Dutch disease. Adam and Bevan (2006) have investigated increasing aid to fund infrastructure with a computable general equilibrium (CGE) model to arrive to this conclusion. In the paper, they show that if non tradable sectors also benefit from infrastructure investment externalities, the negative effect can be attenuated. Moreover, when long term is considered, the negative effects are attenuated. In their paper, they make this demonstration with a theoretic model and construct an aggregated CGE model to verify this and apply it to Ugandan data.

In this paper, we extend this idea by dropping the dichotomous classification of sectors in tradable and non tradable and use more sectors that are not completely tradable or non tradable. In most African countries, we find some sectors as being non tradable (construction sector) and some mostly tradable (rent agriculture and mining) but we generally find sectors with variable relative shares of exports over total production. We extend the idea of Adam and Beven (2006) for differentiated externalities of infrastructure spending and by disaggregating our model we allow for a matrix of externalities between productive sectors and the type of infrastructure expenditure. For this we draw on Savard and Adjovi (1998) in which they analyze the externalities of health and education investment of different productive sectors. We also investigate the sustainability issue but integrating operational and maintenance cost based on findings of Fay and Yepes (2003).

An important literature has demonstrated that public investment in infrastructure taken in the broad sense generates positive production externalities and improves human capital productivity 
(Barro 1991) ${ }^{1}$. The improvement in human capital is generally associated with investments in health and education infrastructure. This phenomenon is even more important in developing countries given the starting point of health and educational indicators in these countries (Davies 2003). A few authors have attempted to take into account the impact of public expenditure in CGE models such as Savard et Adjovi (1998), Anderson and Martin (1998), Fougère and Mérette (1999), Dumont and Mesplé-Somps, (2000), Jung and Thorbecke (2003) and Voyvoda and Yeldan (2005), With the exception of Adam and Bevan (2006), the authors concentrate mostly on health and education expenditure and not infrastructure investments specifically. In our case, we will focus on the implications of increasing investment in infrastructures and funding schemes to fund operating costs of the new infrastructures. As in Adam and Beven (2006), we are interested in investigating the trade impact of these investments in different modes of financings the investments. As there is more and more concern about the negative impact of scaling up aid (see McKinley (2005), Gupta et al (2006) and Foster and Killick (2006)) which is necessary for massive investment in infrastructure. Among the concerns raised by these authors we can state the impact on current account balance or exchange rate and the creation of the Dutch disease.

Our model will also introduce an additional element by imposing increases in public expenditure to maintain and repair the new public infrastructure. This will be included in the government budget constraint and various funding options will be investigated through fiscal policies and foreign aid. By doing a comparative analysis we will be able to see if the results obtained by Adam and Bevan (2006) for Uganda is a special case scenario or if the same type of conclusion is robust to the economic structure of the country analyzed. The models are disaggregated into seven sectors. These sectors allow capturing country specificities in terms of its economic structure. We have selected the following seven sectors as they are quit representative of what is found in most sub-Saharan countries; food crop agriculture, export agriculture, mining and oil, manufacturing, construction, private services and public services. The analysis will focus on a number of items inter alia, differential sectorial impact of the investments, budgetary impact,

\footnotetext{
1 Among these authors, we can refer to Ashauer (1989), Munnell (1990), Bajo-Rubio and Sosvilla-Rivero (1993), Gramlich (1994), and Dessus and Herrera (1996) for production externalities in general as well as Barro (2001), Bils and Klenow (2000) for externalities on human capital.
} 
welfare changes for all agents of the model (households, government, firms and rest of the world), and other macro variables of the model. The choice of the macroeconomic closure of the models will in part determine which variables will be analyzed.

\section{The countries of application and social accounting matrix}

The six countries are selected to represent different types of African countries in terms of geography, demographics and economic characteristics. Countries selected and their characteristics are presented in the following Table 1.

Table 1: presentation of the selected countries

\begin{tabular}{||l||r|r|r|l|l|l||}
\hline Countries & Size (km2) & $\begin{array}{c}\text { Population } \\
\text { (million) }\end{array}$ & GDP/capita & $\begin{array}{c}\text { Main } \\
\text { production }\end{array}$ & Main export & Geography \\
\hline \hline Tanzania & 945000 & 37 & $700 \$$ & Agric & Agric & Costal \\
Uganda & 236000 & 27,2 & $1500 \$$ & Agri-Serv & Coffee & Landlock \\
Senegal & 196000 & 11,1 & $1700 \$$ & Serv & Peanut/fish & Costal \\
Mali & 1240000 & 12,3 & $900 \$$ & Agric & Cotton-gold & Landlock \\
Benin & 112000 & 7,4 & $1200 \$$ & Agric & Cotton & Costal \\
Cameroon & 474000 & 16,3 & $1900 \$$ & Agric-oil & Coffee-Oil & Costal \\
\hline \hline
\end{tabular}

In Table 2, we present a table with the number of sector and the reference year for each social accounting matrix (SAM). Each SAM had to be aggregated to obtain a format as uniform as possible.

Table 2 : presentation of the selected countries

\begin{tabular}{||c||c||c||}
\hline Countries & $\begin{array}{c}\text { Number of } \\
\text { sectors }\end{array}$ & $\begin{array}{c}\text { Reference } \\
\text { year }\end{array}$ \\
\hline \hline Tanzania & 7 & 2000 \\
Uganda & 7 & 1999 \\
Senegal & 6 & 1996 \\
Mali & 7 & 2001 \\
Benin & 5 & 2000 \\
Cameroon & 7 & 2000 \\
\hline
\end{tabular}

\section{The model}

As we mentioned previously, we draw on Adam and Bevan (2006) by using a CGE model to analyse the impact of major investments on infrastructure in African economies but we extend their analysis by using a more disaggregated model as well as operation and maintenance cost. Hence, we can validate if their conclusions hold on an economies with different economic 
structure. The basic elements of the model are drawn from model EXTER of Decaluwé et al (2001) and adjustments were made to introduce infrastructure production externalities and operation and maintenance cost. For production externalities of public investment we introduce a function with sector specific externality elasticity on the different production sectors by drawing on the literature referred to earlier. Each type of public investment will have specific externality elasticities. The four types of investments we will be analyzing in our paper are investment for road infrastructure, electricity, telecom and non productive infrastructure (to be considered as the baseline scenario).

The main hypotheses of our model are that production is determined in the first place through a 3-level system: total production of the branch $(X S)$ is made up of fixed shares for value-added $(V A)$ and intermediate consumptions $(C I)$ as is generally assumed in standard CGE modeling. The relationship determining the level of $V A$ is a Cobb-Douglas type of function between composite labor $(L D)$ and capital $(K D)$. It is in this function that we introduce our infrastructure production externality. This value added function is multiplied by the externality function which is a ratio of new investment over past investment with a sector specific elasticity. We will describe this function below. Producers minimize their cost of producing VA subject to the production function (Cobb-Douglas). Optimal labor demand equations are derived from this cost minimization process. We assume that capital is fixed between sectors as it is quit difficult in the medium term in Africa to convert capital to be used in a another production sector following a policy shock. Intermediate consumptions have been modeled as fixed shares from the input/output ratios calculated on the basis of our six SAM.

We posit, that economies modeled area small open economies, and the world prices of imports and exports are exogenous to the model. We assume the Armington hypothesis (1969) for import demand where domestic consumers can substitute domestically produced goods with imports (imperfectly) with a sector specific elasticity of substitution. The elasticity of substitution depends inter alia on differentiation of the goods, and preference or taste of local consumers. The relative price of the two goods is the other determinant of the ratio of imported goods versus local goods. On the export side, the producers can sell the goods on the local market or export their production and are influenced by relative prices on each market and by their elasticity of 
transformation for the good destined for one or the other market. Labor mobile between sectors and total labor supply is exogenous ${ }^{2}$.

The different agents' income equations are consistent with the structure in our social accounting matrices. Since capital is exogenous, capital payments are endogenous. Hence we have 6 capital payments and one wage. Dividends paid to households are also endogenous and depend of firm's income after taxes. The private firm's income is the balance of capital remuneration not paid directly to households to which must be added government subsidies and transfers from the rest of the world. We will describe the government income below. The Government spends its revenues in different forms such as consumption public goods and services, transfers to households, subsidies to private firms and transfers to the rest of the world and public savings. The government savings is used completely for public investment expenditures.

In our model, we use only one representative household. The goods and services demand functions for this household are derived from a utility maximization process (Cobb-Douglas utility function) subject to a budget constraint. This process generates demand functions which are fixed value share for each goods. Investment demand is decomposed into private and public investment. Private investment is determined by the sum of savings by households, rest of the world (current account balance) and private firms. On the other hand, the public investment is exogenous as we will establish public investment targets to fund new infrastructure and is directly funded by government savings. As we will see, we will allow for different modes to fund the increase in government savings. The two types of investment demand are also specified with a fixed value share function ${ }^{3}$. The final element of demand concerns intermediate consumption. We have already described the demand for intermediate goods which are fixed volume shares based in input-output matrix coefficients.

The price equations are quite standard. We have used the GDP deflator as a price index and it is fixed and used it as the numeraire. As stated earlier herein, world prices for imports and exports are exogenous; accordingly the country has no impact on world market prices.

(2) This does not mean that we assume that there is zero unemployment in the Malian economy but simply that unemployment is exogenous to the model.

${ }^{3}$ In fact, the public investment demand is composed of the construction sector which supply this investment good. The benefits of the investment will be captured by our infrastructure externality elasticity parameter. 
The key assumptions of this model rely on the infrastructure spending which produces positive externalities and these new infrastructure will require increase in government budget to insure appropriate operation and maintenance (O\&M). Hence, it is important describe the equations directly related to these elements. As other equations are relatively standard we will not place more emphasis on a detailed presentation for them ${ }^{4}$. We can first look at the government income sources (equation 1.1). The government draws its revenues from indirect value added taxes $(T i)^{5}$, direct taxes on household (Td) and firms (Tde), import duties (Tim) and export tax $(T e x)^{6}$.

$$
\text { 1. } 1 Y g=\sum_{i m} \operatorname{Tim}_{i m}+\sum_{e x} T e x_{e x}+T d+T d e+\sum_{m} T i_{m}+\operatorname{Trg}+T e g+T g m
$$

The others sources of income are transfers from the three other agents, these can be negative of positive depending on the observed data in the social account matrix. These transfers are the households $(\mathrm{Tgm})$, the firms $(\mathrm{Teg})$ and the rest of the world $(\operatorname{Trg})$. The transfers are always net transfers. Generally the $\operatorname{Tgm}$ is a negative value, representing various forms of subsidies paid by the government to the households. In countries where public firms are still important the transfers from the firms to the government can be positive if the aggregate public firms make profits and negative if they run a deficit. The variables also include subsidies from the government to private and firms. As for the transfers from rest of the world, we represent the net transfers of which we have the foreign aid paid to the governments of which we subtract interest payment made by the government to the rest of the world. All of the variables contributing to the government income can be use to achieve the investment target that will be established for our simulations.

This first equation (1.1) does not provide the full picture of the story as the investment will also be linked to government expenditure on public goods and services. The next equation (1.2) represents the government budget constraint.

$$
1.2 S g=Y g-G
$$

\footnotetext{
${ }^{4}$ The complete set of equations, variables and parameters can be supplied by the authors upon request.

${ }^{5}$ We will refer to this tax as a value added tax even if is more a sales tax than a value added tax.

${ }^{6}$ Export taxes are not applied in all countries modeled.
} 
The government spends its income $(Y g)$ either on public goods and services $(G)$ or on savings $(S g)$. The government savings will entirely be used for public investment (Itp).

At this point, the closure rule used for balancing this budget constraint will be a key element for our analysis. We will introduce an additional assumption that a percentage increase in public investment on infrastructure will require an increase in O\&M cost of these new infrastructures. Hence, the level of government expenditure $(G)$ on public goods and services will be a function of its original level of expenditure $(G o)$ to which we add the new O\&M cost for the new infrastructures. Since, empirical studies have shown that new public infrastructure generates an additional O\&M cost which varies from regions to type of infrastructure investment, we will have a specific share parameter for each forms of investment. Hence, we will multiply the specific share parameter $(\omega)$ to the increase in public investment (Itp - Itpo), where Itpo is the public investment at the reference period. The value will represent the increase in O\&M cost for the new infrastructure to which we add the original value of government expenditure that is held fixed in the model. The total government expenditure will $(G)$ will be determined by the following equation:

$$
\text { 1. } 3 G=G o+\omega(\text { Itp - Itpo })
$$

To determine the value to be attributed to our $\omega$ parameter we draw on Fay and Yepes (2003) who measured needs in investments and O\&M cost for different types of public infrastructure investments for 2005-2010 in sub-Saharan Africa. To obtain our share parameters we simply computed that ratio between investment needs and O\&M cost.

Table 3: Value for $\omega$

\begin{tabular}{|l|c|}
\hline \multicolumn{2}{|c|}{$\omega$ paramters } \\
\hline Road & 0,84 \\
\hline Electricity & 0,9 \\
\hline Telecom & 0,74 \\
\hline
\end{tabular}

This assumption of public expenditure is equivalent to fixing public expenditure. As we will fix investment objectives, the public investment (Itp) will also be exogenous and implicitly the government savings will also be exogenous given the identity of equation 1.4.

$$
\text { 1. } 4 \text { Itp }=S g
$$


Given these assumptions, only one element can adjust to clear the government budget constraint (equation 1.2) and that is the government income $(Y g)$. As this variable is not free in the model since it is determined by; the income generated from other agents, level of production in different branches and level of imports and exports, we will need to free one variable in equation 1.1. In practice, we could use any one of the variables or sub variables on the right hand side to balance the government budget constraint. One option would be to leave the $\operatorname{Trg}$ endogenous which would mean that the objectives for public infrastructure investment and O\&M will be achieved by an increase in foreign aid. Another option is to leave one of the tax rates (household income tax, firms' income tax, sale tax and import duties) endogenous. Finally, the transfers from households and firms could also be left endogenous. Any joint options could also be simulated.

The other specific assumption in our CGE model is the externality equation (1.5) and its role in increase total productivity of factors of the value added (equation 1.6). For this, we draw on the vast literature linking public infrastructure to private sector factor productivity and we use the approach proposed by Dumont and Mesplé-Somps (2000) in a CGE context. Our approach differs slightly from theirs as we do not use private investment in our externality function. The externality function defined by the following function:

$$
1.5 \theta_{i}=(\operatorname{Itp} / \text { Itpo })^{\xi_{i}}
$$

where $\theta_{i}$ is the externality or sectoral productivity effect which is a function of the ratio of new public investment (Itp) over public investment (Itpo) at the reference period with a sector specific elasticity $\left(\xi_{i}\right)$. Values selected for $\xi_{i}$ are presented in Table 3.

Table 4: Value for $\xi$

\begin{tabular}{|c|c|c|c|c|c|c|}
\hline \multicolumn{7}{|c|}{$\xi$ paramters } \\
\hline \hline $\begin{array}{c}\text { Sectors } \\
\text { Investment }\end{array}$ & $\begin{array}{c}\text { Crop } \\
\text { agriculture }\end{array}$ & $\begin{array}{c}\text { Export } \\
\text { agriculture }\end{array}$ & $\begin{array}{c}\text { Mining \& } \\
\text { Gas }\end{array}$ & Industries & Construction & $\begin{array}{c}\text { Private } \\
\text { Services }\end{array}$ \\
\hline Road & 0.05 & 0.075 & 0.085 & 0.035 & 0.055 & 0.025 \\
\hline Electricity & 0.001 & 0.015 & 0.02 & 0.1 & 0.075 & 0.055 \\
\hline Telecom & 0.02 & 0.025 & 0.015 & 0.015 & 0.045 & 0.035 \\
\hline
\end{tabular}

We do not model private sector eviction effect explicitly but it is captured indirectly in some scenarios. The externality of public infrastructure investment produces an increase in total factor productivity. This link to the value added $(\mathrm{Va})$ is taken into account in the Cobb-Douglas function of the following equation: 


$$
\text { 1. } 6 V a_{m}=\theta_{i} A_{m} L d_{m}^{\alpha_{m}} K d_{m}{ }^{1-\alpha_{m}}
$$

where $A_{i}$ is the scale parameter for sector i, $L d_{i}$, the labor demand for sector i, $K d_{i}$, the capital used in sector $i \mathrm{I}$, and $\alpha$ the Cobb-Douglas parameter. Hence, an increase in $\theta_{i}$ represents a Hicks' neutral productivity improvement such as modeled in Yeaple and Golub (2007) ${ }^{7}$. With this formulation, the infrastructure investment can thus act as a source of comparative advantage since the function is sector specific. The sector specific elasticity allows us to capture the different impact the investment will have on specific sectors. For example, road investment will benefit more the export agriculture compared to the construction sector.

Model equilibrium conditions are also standard. The commodity market is balanced by an adjustment of the market price for each commodity. The labor market balances out with an adjustment of the nominal wage. The current account balance is fixed and the nominal exchange rate adjusts to allow the real exchange rate to clear the current account balance.

The same archetype model is applied to all six other countries. Minor adjustments will be needed to take into account the different fiscal structure of countries and the agents' transfer matrix. The externality elasticities, trade elasticities and O\&M cost parameters are identical in all models. Differences in results will come uniquely from the differences in the structure of the economies.

It is important to highlight an element before moving on to the simulations. In our model, we will simulate increases in taxes and transfers to achieve the investment objectives and O\&M cost. In a standard CGE model, the funding needs would be greater then our simulated results as these models assume that infrastructure investments do not produce production externalities. The externalities generate a growth effect and the additional output will produce more income for the government.

\section{The pros of the approach:}

The advantages of using CGE model as an analytical tool for impact assessment of increase in public investment on public infrastructure. The CGE models used in this study will allow investigating in more detail the consequences in increasing public infrastructure in African economies. The archetype model uses a larger number of agents compared to more standard

\footnotetext{
7 This formulation is also commonly used in the literature estimating parameters of the externalities of public infrastructure on total factor productivity such as Ashauer (1989), Munnell (199), Bajo-Rubio and Sosvilla-Rivero (1993), Gramlich (1994), and Dessus and Herrera (1996) among others.
} 
macro type models. We explicitly have four agents in the model, namely households, the firms, the government and the rest of the world. The other main advantage of this model compared to the Adam and Beven (2006) model is that we use more production sectors. In their study Adam and Bevan (2006) explicitly introduce an import competing sector, an export sector and non tradable. This is interesting for illustrative purposes. However, as illustrated by most disaggregated social accounting matrix in Africa, few sectors can be classified in pure tradable or non tradable sectors. Most often, sectors exhibit variable degree of openness to trade. Generally, the construction sector in non tradable, and even the agricultural sector cannot by described as fully tradable or non tradable. We observe some export in subsistence agriculture in most African countries. In some of them, the proportion of exports on total production can be relatively large. As for export crops, the rate of exports on total production can also by quit variable. The service sector is also one in which we observe a fair amount of differences from one country to the other. By using this decomposition instead of the one used by Adam and Beven (2006), the Dutch disease effects might be even smaller then what they have obtained.

The CGE model presented here has the advantage of being fully coherent where all accounts must be balanced such as government (described at length earlier), current account balance and we have information on the pressures that will be put on the real exchange rate. This model will also allow us to identify the winners and losers of the different scenarios to be analysed, simulate various fiscal policies to fund the investment and provide a comparative analysis in terms of winners and losers. Hence, we provide a comparative analysis between different countries and illustrate the importance or non importance of the structural differences between six African countries. We also compare different funding options for the infrastructure investment, in terms of distributional impact as well effects in real exchange rate, and efficiency.

\section{A structural comparison of the economies analyzed}

In this section, we present tables in which we highlight the structural differences and similarities of the selected countries. We do not present the complete SAM for the economies but focus on a few structural characteristics of importance for the analysis. As in all CGE models, the labor/capital ratio of the production sectors always play an important role in the results obtained from policy simulation. Other ratios of importance are the weight of the sectors in the GDP, the export/output ratio and the import/total consumption ratio. 
Let us first look at the weight of sectors in the total GDP. In the following table we present these weights for each country.

Table 5: Weight of the productive sectors in total GDP

\begin{tabular}{||l||c||c||c||c||c||c||c||}
\hline & $\begin{array}{c}\text { Crop } \\
\text { agriculture }\end{array}$ & $\begin{array}{c}\text { Export } \\
\text { agriculture }\end{array}$ & $\begin{array}{c}\text { Mining } \\
\text { and Gas }\end{array}$ & Industries & Construction & $\begin{array}{c}\text { Private } \\
\text { Services }\end{array}$ & $\begin{array}{c}\text { Public } \\
\text { services }\end{array}$ \\
\hline \hline Benin & 0,35 & 0,07 & & 0,14 & & 0,36 & 0,07 \\
Cameroon & 0,17 & 0,07 & 0,10 & 0,20 & 0,02 & 0,35 & 0,10 \\
Mali & 0,21 & 0,16 & 0,11 & 0,09 & 0,06 & 0,28 & 0,07 \\
Senegal & 0,12 & 0,11 & & 0,17 & 0,04 & 0,47 & 0,09 \\
Tanzania & 0,26 & 0,17 & 0,02 & 0,16 & 0,10 & 0,22 & 0,06 \\
Uganda & 0,32 & 0,13 & 0,0007 & 0,11 & 0,08 & 0,31 & 0,04 \\
\hline
\end{tabular}

From this table, we note that Senegal and Cameroon have the two economies relying the less on agriculture, with $23 \%$ and $24 \%$ respectively. For all other countries, the weight of agriculture is between 37\% (for Mali) and 45\% (for Uganda). Benin and Cameroon are the two countries which have the smallest export agriculture sectors (7\%) and Tanzania the largest at 17\%. Mining and Gas is an important sector for Cameroon and Mali where the oil sector is large for Cameroon and the mines (gold) for the Malian economy (11\%). The industrial sector is relatively small in all countries ranging from $9 \%$ in Mali and 20\% in Cameroon. The construction sector accounts only for $2 \%$ of the Cameroonian economy whereas it represents $10 \%$ for Tanzania. Other countries are between these two extremes cases. The largest country differences are certainly found in the private services where we have Senegal where close to half its economy relies on services (47\%) and Tanzania at only $22 \%$. Public services are quit similar with most country around $8 \%$ with the two extremes being Cameroon with $10 \%$ on the higher end and Uganda on the lower end at $4 \%$.

In Table 6, we present the labour/capital ratio for each country. This is important as pressures on factor market will benefit labour intensive or capital intensive sector depending of the policy 
simulated. Hence these ratios will be informative for the sectoral analysis that will be performed below ${ }^{8}$.

Table 6: Labour/capital ratios by sector and countries

\begin{tabular}{||l||c||c||c||c||c||c||c||}
\hline \hline & $\begin{array}{c}\text { Crop } \\
\text { agriculture }\end{array}$ & $\begin{array}{c}\text { Export } \\
\text { agriculture }\end{array}$ & $\begin{array}{c}\text { Mining } \\
\text { and Gas }\end{array}$ & Industries & Construction & $\begin{array}{c}\text { Private } \\
\text { Services }\end{array}$ & $\begin{array}{c}\text { Public } \\
\text { services }\end{array}$ \\
\hline \hline Benin & 0,03 & 0,03 & N/A & 0,20 & N/A & 0,20 & 1,00 \\
Cameroon & 3,69 & 1,01 & 0,03 & 0,66 & 5,09 & 0,98 & 1,00 \\
Mali & 0,13 & 0,07 & 0,11 & 0,64 & 2,38 & 0,30 & 1,00 \\
Senegal & 0,02 & 0,64 & N/A & 0,32 & 0,21 & 0,21 & 1,00 \\
Tanzania & 2,83 & 1,74 & 0,07 & 1,08 & 0,59 & 0,53 & 1,00 \\
Uganda & 1,07 & 0,94 & 0,28 & 0,88 & 1,43 & 1,42 & 1,00 \\
\hline
\end{tabular}

One tendency that emerges is the fact that crop agriculture is more labour intensive than the export agriculture with the exception of Senegal. In Senegal, the export agriculture is mostly groundnut which is very labour intensive. The mining sector is very capital intensive, especially the oil sector in Cameroon and the least intensive the in Uganda (28\%). For the industries, we observe a fair amount of differences with Tanzania that has a very labour intensive industry with a ratio above 1 (1.08) and the least intensive is the Benin (cotton) with a ratio of 0.2. Construction is also labour intensive except in Senegal and Tanzania and Private services is very labour intensive in Uganda (1.43) and small in Benin (0.2) and Senegal (0.21).

The next structural feature is the exports on total output by sector which is presented in Table 7 .

Table 7: Export/output ratios by sector and countries

\begin{tabular}{||l||c||c||c||c||c||c||}
\hline \hline & $\begin{array}{c}\text { Crop } \\
\text { agriculture }\end{array}$ & $\begin{array}{c}\text { Export } \\
\text { agriculture }\end{array}$ & $\begin{array}{c}\text { Mining } \\
\text { and Gas }\end{array}$ & Industries & Construction & $\begin{array}{c}\text { Private } \\
\text { Services }\end{array}$ \\
\hline \hline Benin & 0,06 & 0,08 & N/A & 0,18 & N/A & 0,38 \\
Cameroon & 0,01 & 0,12 & 0,95 & 0,15 & 0,00 & 0,07 \\
Mali & 0,04 & 0,33 & 1,00 & 0,002 & 0,00 & 0,09 \\
Senegal & 0,01 & 0,06 & N/A & 0,32 & 0,01 & 0,12 \\
Tanzania & 0,03 & 0,15 & 0,09 & 0,02 & 0,41 & 0,04 \\
Uganda & 0,01 & 0,04 & 0,00 & 0,23 & 0,00 & 0,06 \\
\hline \hline
\end{tabular}

\footnotetext{
${ }^{8}$ It is important to highlight the fact that a different methodological approach is at the source of important differences observed in this table. By common practice, national accounts classify the small household farmers' surplus into the capital account. In the modelling world some are of the view that this should not be maintained in a SAM and corrected to be placed in the labour payment account. As we did not have full information of what was done in each SAM we did not modify them. However, we clearly see that some modellers have modified these numbers namely in Cameroon, Tanzania and probably in Uganda. In the three other countries, the modellers have probably kept the SAM structure as was found in the input-output table. This explains the big differences for the two agricultural sectors.
} 
An interesting feature of this table is that we observe relatively same ratio for the export agriculture sectors. This is explained by the fact that a large part of the products undergo a first round of transformation by the industrial sector before being exported. The other surprising figure is the $41 \%$ for the construction sector being exported by Tanzania. Some of the countries export a large part of their industrial production, such as Senegal (32\%) and Uganda (23\%) and other very little, Mali with $0.2 \%$ and Tanzania $2 \%$. As for private services we also have large differences between countries ranging from $38 \%$ in Benin to $4 \%$ in Tanzania. The most important export sector for Tanzania and Mali in relative terms is export agriculture, for Uganda it is industry, for Senegal as well, for Benin it is private services and finally Cameroon it is the Mining and Oil sector. The final structural feature we are presenting is the imported goods over the total national consumption, which includes final household and government consumptions, intermediate inputs to the sectors and demand for investments goods. The ratios are presented in Table 8 .

Table 8: Import/total demand ratios by sector and countries

\begin{tabular}{||l||c||c||c||c||c|c||}
\hline \hline & $\begin{array}{c}\text { Crop } \\
\text { agriculture }\end{array}$ & $\begin{array}{c}\text { Export } \\
\text { agriculture }\end{array}$ & $\begin{array}{c}\text { Mining } \\
\text { and Gas }\end{array}$ & Industries & Construction & $\begin{array}{c}\text { Private } \\
\text { Services }\end{array}$ \\
\hline \hline Benin & 0,05 & 0,00 & & 0,27 & & 0,03 \\
Cameroon & 0,01 & 0,03 & 0,88 & 0,22 & 0,01 & 0,07 \\
Mali & 0,04 & 0,09 & 0,00 & 0,61 & 0,00 & 0,06 \\
Senegal & 0,25 & 0,04 & N/A & 0,39 & 0,00 & 0,08 \\
Tanzania & 0,02 & 0,05 & 0,60 & 0,30 & 0,32 & 0,03 \\
Uganda & 0,01 & 0,00 & 0,75 & 0,39 & 0,00 & 0,10 \\
\hline \hline
\end{tabular}

In this table, we note some interesting features, namely for the agricultural sectors. Senegal is the only big importer of crop agriculture (25\%) where all other countries are below 5\%. For the export agriculture, four countries import some goods; and these are likely destined to the industrial sector transforming these goods. Mining and Gas is an important imported good in Cameroon, Tanzania and Uganda. All countries have high import ratios for industrial goods with the exception of Cameroon (22\%). Once again, we have an unusually high import of construction good or services for Tanzania 32\% when we observe close to 0 figures for other countries. The imports of private services range from 3\% for Tanzania and 10\% for Uganda. 
In light of the figures, and other differences we can expect to observe differentiated effects of our simulations of the different economies. The other structural features that we do not present here but will play a role are the structure of the public investment, structure of household consumption and the fiscal structure of the governments.

\section{Simulation description}

In order to analyse the impact of increasing investment in infrastructure and different funding mechanisms, we isolate three types of infrastructure investments and perform a baseline set of simulations on unproductive investment to provide a reference point for the comparative analysis. Hence, we present four sets of simulations. The first one is the baseline non productive investments, the second the investment in road infrastructure, the third on electricity and the last one on telecom infrastructure. We then perform five simulations within each of the productive investment and four for the unproductive investment. The productive investments are distinguished uniquely by the externality parameters. The scale of the public investment on the infrastructure is maintained constant throughout the simulations. We perform an increase of $20 \%$ of public investment on infrastructure.

Let us describe these five funding options analysed. In the first funding scheme, we have decrease in other public expenditure to fund the investments and their O\&M costs. In the second funding option, we increase the value added tax (Ti) in the economy, in the third, we increase import duties, in the fourth foreign aid is the source of funding and finally the last option it is an increase in income taxes that provides the required funds. This comparative analysis will allow us to highlight the most efficient funding mechanism and to explore the effects on different macroeconomic and sectorial variables. We present the simulations in a synthetic form in Table 9:

Table 9: Presentation of the simulation

\begin{tabular}{||c||l||}
\hline \multirow{4}{*}{$\begin{array}{c}\text { 1- Non productive } \\
\text { investment }\end{array}$} & 1-a) VAT funding* \\
\cline { 2 - 3 } & 1-b) Import duties funding \\
\cline { 2 - 3 } & 1-c) Foreign Aid funding \\
\cline { 2 - 3 } & 1-d) Income tax funding \\
\hline \multirow{2}{*}{ 2-Roat } & 2-a) Reduction in other public expenditure \\
\hline
\end{tabular}




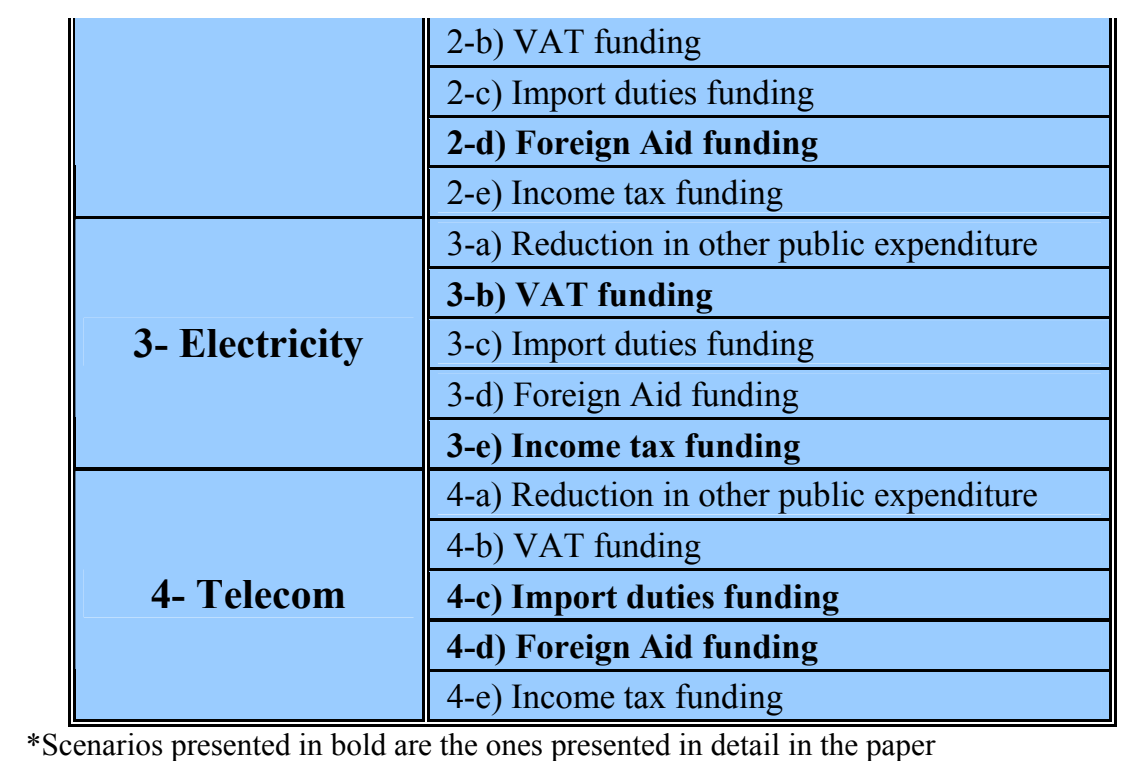

As these simulations were performed on six country models, we generated 114 simulations. We provide key results. For the impact analysis we have selected two funding scheme for each type of investments. In the following section, we concentrate on the macroeconomic variables to simplify the presentation but we highlight the main sectorial effects for one funding options for each types of investment. We proceed by doing a detailed comparative analysis between the countries for two funding options for the four different types of investment strategies. Hence, we analyse in more detail 8 of the 19 scenarios for six countries. Tables are presented with the investment options and the funding schemes. This approach facilitates the comparative analysis of the investment strategies and the efficiency of different funding modalities.

\section{Impact analysis of scenarios}

We will start by presenting the unproductive investment option which can be considered the baseline scenario. An important element to highlight before moving to the analysis is that in each productive investment scenarios, we will observe an increase in GDP which is a direct consequence of our externality hypothesis. As we have assumed that our total endowment of productive factors is exogenous, growth in GDP is generated directly by our production externalities of our public investment. The relative importance of this increase between the sets of simulation is directly determined by the externality elasticities we have selected and the relative importance of the sectors in the economy. Anther key hypothesis to keep in mind when looking at result is the fact that we have maintained our current account balance fixed. The current account is balanced by an adjustment of the nominal exchange rate. Finally, in the tables, 
we present the nominal exchange rate but this can also be interpreted as the real exchange rate since our price index (GDP deflator) is exogenous and hence the variation in the nominal exchange rate is equivalent to the variation in the real exchange rate.

An additional comment needs to be formulated before moving to the analysis. For Uganda, we have only increase public investment by $5 \%$. We were constrained to this given the high level of public investment at the reference period. Simulating a $20 \%$ increase was not possible for the foreign aid funding scenario. Given the nominal increase in size, it produced an excessive pressure on the nominal exchange rate.

\subsection{The investment in non-productive infrastructure}

These scenarios (Set 1) can be interpreted as an investment in the construction of monuments, in the army (if the country is not in conflict) or other types of non productive investments by the government. We analyse at two funding options to increase the non productive public investment. The first one is an increase in the value added tax and the second is an increase in import duties. Let us analyse the simulations for the six countries.

\subsubsection{Investment funded by the value added tax}

In this simulation (1a) we increased the non productive public investment (investment which does not produce production externalities on other productive sectors of the economy) the increase in spending by the government is funded by a uniform increase of the effective value added tax. At the reference period the value added tax (VAT) are not uniform and the differentiated structure remains after simulation. We apply a uniform tax increase and hence, the percentage adjustment is the same for all sectors if the tax rate in the sector is positive at the reference period but nominal changes can be quit different. We hold exogenous the other public expenditure made by government but assume as was explained earlier that the new investment will require some new O\&M expenditure. Hence, the $20 \%$ increase in government saving and the new public expenditure for O\&M cost of the new investment is funded by the increase in value added tax. In this simulation, as in others, an important structural distinction between the countries is the initial public investment. If this is very low at the reference period, the $20 \%$ increase will be smaller in nominal terms then in the countries were the reference period public investment is large. Let us first look at the macro results for all countries in Table 10. 
Table 10: Macroeconomic results for non-productive investments, VAT funded

\begin{tabular}{|c|c|c|c|c|c|c|c|}
\hline \multirow[b]{2}{*}{ Variables } & \multirow[b]{2}{*}{ Definition } & \multicolumn{6}{|c|}{ Non productive investment (VAT funded) } \\
\hline & & Benin & Mali & Senegal & Tanzania & Uganda & Cameroon \\
\hline$Y m$ & Aggregate household income & 0.09 & 0.06 & 0.29 & 0.02 & 0.02 & 0.25 \\
\hline$E V$ & Equivalent variation & 0.09 & 0.06 & 0.26 & 0.02 & 0.02 & 0.23 \\
\hline$s$ & Wage & 4.42 & 0.49 & 1.29 & 0.07 & 0.11 & 0.56 \\
\hline yg & Government income & 14.70 & 3.19 & 5.90 & 5.44 & 3.14 & 6.36 \\
\hline ye & Firms income & -0.71 & -0.18 & -0.45 & -0.08 & -0.13 & -0.64 \\
\hline$g$ & Total government expenditure & 11.96 & 1.73 & 5.38 & 3.52 & 2.49 & 7.27 \\
\hline It & Total private investment & 0.04 & -0.17 & -0.45 & -0.13 & -0.16 & -0.86 \\
\hline$e$ & nominal exchange rate & 1.69 & 0.03 & 0.07 & 0.02 & -0.12 & 0.35 \\
\hline GDP & GDP & 0.02 & 0.00 & 0.01 & 0.00 & 0.00 & 0.00 \\
\hline
\end{tabular}

A first observation is that for all countries, this option seems to favour households over firms. This comes from that fact that the wage increases versus the average rental rate of capital in each country. This increase in government income reflects the fact that we increased the VAT to fund the new investment. As the investment in public expenditure does not produce externalities, the government does not benefit from an increase in income from economic growth. Hence, the increase in income mostly attributed to the increase in the VAT needed to fund O\&M cost of new public investments. This will be useful for comparative purposes in the next scenarios to see how growth influences government income. The other common feature is that the simulation produces an increase in wages and this come from the fact that the public services must increase for the O\&M of new investment and since this sector uses exclusively labour; this puts more pressure on the labour market than on the capital market.

Comparing the impact on the household income, we observe an increase for all countries with the strongest impact for Senegal and Cameroon. This is a consequence of the stronger increase in wage for these two countries. Accordingly, the strongest decrease in firms' income is also observed in these two countries. The total private investment decreases in all countries (eviction of private investment for the public investment) with the exception of Benin but the increase in private investment in Benin is very small $(+0.04 \%)$.

\subsubsection{Investment funded by import duties}


For the import duties funding option (1b), we analyse both the macro and sectorial results. In this case, we let the import duties adjust uniformly from the reference situation. The macro results are presented in Table 11.

Table 11: Macroeconomic results for non-productive investments, Import duties funded

\begin{tabular}{|c|c|c|c|c|c|c|c|}
\hline \multirow[b]{2}{*}{ Variables } & \multirow[b]{2}{*}{ Definition } & \multicolumn{6}{|c|}{ Non productive investment (import duties funded) } \\
\hline & & Benin & Mali & Senegal & Tanzania & Uganda & Cameroon \\
\hline$Y m$ & Aggregate household income & 0.10 & 0.08 & 0.29 & 0.04 & 0.02 & 0.35 \\
\hline$E V$ & Equivalent variation & 0.09 & 0.08 & 0.26 & 0.04 & 0.02 & 0.32 \\
\hline$s$ & Wage & 4.81 & 0.72 & 1.27 & 0.10 & 0.11 & 0.78 \\
\hline$y g$ & Government income & 14.70 & 3.19 & 5.90 & 5.44 & 3.14 & 6.36 \\
\hline ye & Firms income & -0.77 & -0.26 & -0.44 & -0.13 & -0.14 & -0.89 \\
\hline$g$ & Total government expenditure & 11.96 & 1.73 & 5.38 & 3.52 & 2.49 & 7.27 \\
\hline It & Total private investment & -0.18 & -0.25 & -0.65 & -0.52 & -0.85 & -1.16 \\
\hline$e$ & nominal exchange rate & -1.20 & -0.70 & -1.38 & -1.00 & -2.39 & -1.92 \\
\hline$G D P$ & $G D P$ & 0.01 & 0.00 & 0.01 & 0.00 & 0.00 & 0.00 \\
\hline
\end{tabular}

At the macro level, the results are quit similar to the VAT funded scenario. The relative impact on household income and equivalent variation and firms' income are almost identical for all countries with the exception of Cameroon with slightly stronger effects. By definition, the government income variation is the same as we have explained in the previous section. The negative effect is stronger for all countries on the private investment compared to simulation 1a and we observe the positive effect in Benin moving to a negative effect. The largest difference between the two funding options for this variable is observed for Uganda going from $-0.16 \%$ to $-0.85 \%$. It is now interesting to look at the sectorial effect of this investment option and funding scenario. Results are presented in Table 12.

Table 12: Sectoral results for non-productive investments, Import duties funded

\begin{tabular}{||c||c||c|c|c|c|c|c||}
\hline \multicolumn{2}{||c||}{} & \multicolumn{5}{c||}{ Non productive investment (Import duties) } \\
\hline \hline Variables & branches & Benin & Mali & Senegal & Tanzania & Uganda & Cameroon \\
\cline { 2 - 8 } & Crop agriculture & -0.14 & -0.08 & -0.03 & -0.14 & -0.08 & -0.87 \\
Va & Export agriculture & -0.19 & -0.07 & -0.95 & -0.38 & -0.27 & -0.60 \\
(Value & Mining and Gas & & -0.25 & & -0.04 & 0.06 & -0.10 \\
added or & Industries & -0.65 & -0.15 & -1.08 & -0.25 & -0.64 & -0.60 \\
output) & Construction & & 0.47 & 1.88 & 0.17 & 1.05 & 5.24 \\
& Private Services & -1.10 & -0.14 & -0.35 & -0.09 & -0.12 & -0.52 \\
& Public services & 7.60 & 1.09 & 4.24 & 2.32 & 2.27 & 4.19
\end{tabular}




\begin{tabular}{|c|c|c|c|c|c|c|c|}
\hline Variables & branches & & & & & & \\
\hline \multirow{7}{*}{$\begin{array}{c}p q \\
\text { (Market } \\
\text { prices) }\end{array}$} & Crop agriculture & 0.25 & 0.18 & -0.08 & 0.14 & 0.07 & 0.74 \\
\hline & Export agriculture & -1.08 & 0.00 & 0.38 & 0.47 & -0.04 & 1.67 \\
\hline & Mining and Gas & & -0.31 & & 0.23 & 1.71 & 0.71 \\
\hline & Industries & 3.38 & 0.65 & 1.69 & 0.54 & 0.02 & 2.65 \\
\hline & Construction & & 0.65 & 6.07 & 0.60 & 0.49 & 2.24 \\
\hline & Private Services & 0.80 & 0.35 & 0.28 & 0.10 & 0.15 & 0.73 \\
\hline & Public services & 4.05 & 0.61 & 1.09 & 0.18 & 0.21 & 1.13 \\
\hline Variables & branches & & & & & & \\
\hline \multirow{6}{*}{$\begin{array}{c}r \\
\text { (rental rate } \\
\text { of capital) }\end{array}$} & Crop agriculture & -0.49 & 0.01 & -0.13 & -0.09 & -0.03 & -0.34 \\
\hline & Export agriculture & -2.42 & -0.44 & -1.19 & -0.49 & -0.45 & -0.42 \\
\hline & Mining and Gas & & -1.83 & & -0.51 & 0.40 & -2.84 \\
\hline & Industries & 0.86 & 0.32 & -3.17 & -0.37 & -1.26 & -0.73 \\
\hline & Construction & & 1.39 & 12.88 & 0.58 & 1.91 & 7.12 \\
\hline & Private Services & -1.85 & 0.09 & -0.72 & -0.14 & -0.10 & -0.27 \\
\hline
\end{tabular}

A common effect across the countries (in fact, this is observed in the four investment scenarios) is the stronger increases of output for publics services compared to other productive sectors ${ }^{9}$. This occurs by definition given our O\&M cost constraint imposed as well as the fact that the construction sector benefits directly from the public investment. Given our hypothesis of fixing total production factors in the model, the increase in output of these two sectors is compensated by a reduction of output for all other sectors and this is valid in all countries. Since we do not have investment externalities in this scenario, labour is taken from these other sectors for the increase of the construction and public services sector. We only observe one exception of this situation and it is for the Mining and Gas sector in Uganda which increases its output slightly by $0.06 \%$. This comes from the fact that the sector in Uganda is very small (0.07\% of the GDP) and it is capital intensive. Given the pressure on the labour market which generates an increase on the wage in all countries, the sectors that are more intensive in labour are penalized versus the capital intensive ones. This factor intensity by sectors in the different countries is the other important factor producing sectoral differences. When looking at the most negatively affected sector, no clear tendency is observed. In fact in each country we find a different sector with the exception of Senegal and Uganda where it is the industrial sector that is most concerned. In Benin it is the private services, crop agriculture in Cameroon, in Mali the Mining and Gas and in

9 Value added and output exhibit the same variation changes as they are linked with a fixed share parameter from the Leontief hypothesis. 
Tanzania the export agriculture. Hence, the policy and funding scheme does not produce uniform sectorial results between countries and therefore we can say that the structural effects of the economies dominate the behavioural effects in this respect.

As for the price effects, our increase in import duties produce an increase in most prices in most countries but the dominating effect on prices remains on the demand side for the construction sector. Given the increase in demand for construction good via the increase in public investment, we observe the strongest price increase (or second biggest) for this sector in all countries. In general the crop agriculture and private services sector seem to be the least affected in most countries. As we have already mentioned, the pressure on the factor markets is on labour and we observe an increase in wage in all countries. This implies that the capital becomes relatively more abundant and its prices (rental rate of capital) decreases in most sectors and for all countries. We observe a few exceptions to this trend such as for the industry in Benin and Mali and mining and gas in Uganda. The rental rate of capital in the construction sector increases in all countries once again given the strong pressure from the demand side.

\subsection{The investment in road infrastructure}

Moving on to the road investment option (Set 2), we are now analyzing scenarios with production externalities. The first systematic difference with the baseline scenario is the fact that we observe increases in GDP generated by the sector specific externalities associated with road investments. This will add some sectoral differences compared to the baseline simulations.

\subsubsection{Investment funded by foreign aid}

In this scenario (2d), we assume that the new investment is funded by a grant from a foreign donor (Foreign aid). Results are presented in Table 13.

Table 13: Macroeconomic results for road investments, funded by foreign aid

\begin{tabular}{|c|c|c|c|c|c|c|c|}
\hline \multirow[b]{2}{*}{ Variables } & \multirow[b]{2}{*}{ Definition } & \multicolumn{6}{|c|}{ Road (Foreign aid funded) } \\
\hline & & Benin & Mali & Senegal & Tanzania & Uganda & Cameroon \\
\hline$Y m$ & Aggregate household income & 0.74 & 0.87 & 1.01 & 0.55 & 0.21 & 1.07 \\
\hline $\boldsymbol{E} \boldsymbol{V}$ & Equivalent variation & 0.75 & 0.89 & 1.00 & 0.55 & 0.25 & 1.12 \\
\hline$s$ & Wage & 4.88 & 1.77 & 2.00 & 0.82 & 0.42 & 1.84 \\
\hline yg & Government income & 13.53 & 2.93 & 5.43 & 5.00 & 2.89 & 5.85 \\
\hline ye & Firms income & -0.12 & 0.51 & 0.69 & 0.80 & -0.05 & -0.62 \\
\hline$g$ & Total government expenditure & 10.05 & 1.46 & 4.52 & 2.96 & 2.09 & 6.11 \\
\hline It & Total private investment & 0.17 & 0.71 & 0.04 & 1.31 & -3.45 & -0.27 \\
\hline
\end{tabular}




\begin{tabular}{||c||c||c|c|c|c|c|c||}
$\boldsymbol{e}$ & nominal exchange rate & -4.85 & -2.25 & -4.24 & -1.61 & -11.68 & -6.31 \\
\hline $\boldsymbol{G D P}$ & $\boldsymbol{G D P}$ & 0.69 & 0.84 & 1.03 & 0.81 & 0.21 & 0.70 \\
\hline
\end{tabular}

Lets first highlight the differences observed for changes in GDP between countries. In Benin, the GDP increases by only $0.69 \%$ where an increase of $1.03 \%$ is observed for Senegal and $0.84 \%$ for Mali $^{10}$ as seen in the Graph 1. Once again, the differences are not major but considering that behavioural equations and externality elasticities are the same, these differences originate from the sectoral structure of the GDP in the different countries. If a sector is larger and it receives a smaller externality effect, the country will benefit less compared to countries where the larger sector benefits the most from road investment externalities. The analysis of the equivalent variation reveals a stronger welfare gain for households in Cameroon, followed by Senegal and the weakest positive effect is in Tanzania. In some countries, the positive impact on households (equivalent variation) is similar to the change in GDP such as Senegal and quit different in others namely in Cameroon and Tanzania. Contrary to the baseline scenario, we don't systematically have the households being the winners versus the firms. Indeed, it is the case for 5 of the 6 countries but in Tanzania, the firms are the biggest winners. Moreover, in the baseline scenario, the firms were losers in all countries and in this case, the firms' increase their revenues in three countries and the ones where it decreases the reductions in firms' income are smaller compared to the baseline case. There are also relatively large differences for the change in wage, although it still increases in all countries. The increases in wage rate range from $0.42 \%$ in Uganda to $4.88 \%$ in Benin.

\section{Graph 1 : GDP and EV changes for road investments, funded by foreign aid}

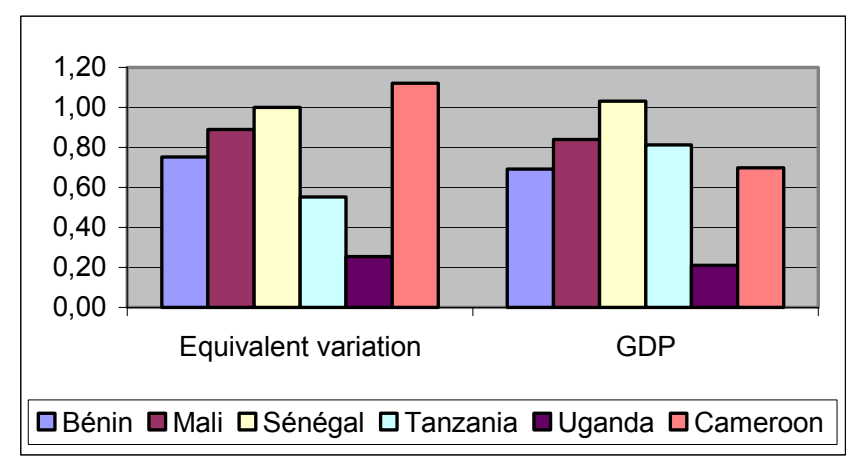

10 As we have mentioned the investment change simulated in Uganda we one quarter of what was performed in other countries. This result on GDP for Uganda is around one quarter of Tanzania and Mali. 
Given the better performance of the private firms as well as households, the economy generates more private saving and therefore, the private investment increases in four countries, decreasing only in Uganda and Cameroon. This funding option combined with our exogenous current account balance produced strong pressure on the nominal exchange rate ${ }^{11}$. Since we impose an inflow of funds and the current account balance (CAB) must remain constant, we will need to import more and export less to balance the $\mathrm{CAB}$ and this occurs with an appreciation of the nominal exchange rate. Hence, we observe a decrease in the nominal exchange rate in all countries. The importance in the reduction is strongly related to the relative importance of foreign aid needed to fund the road construction. For example, the strongest appreciation is in Uganda with a decrease of the nominal exchange rate by $11.7 \%$ and the weakest appreciation is in Tanzania with a decrease of $1.6 \%$.

\subsubsection{Investment funded by a reduction of other public expenditure}

The next simulation is the same road investment but this time it is financed through a reduction of other public expenditure (2a). The government needs to reduce its supply of other services to fund the construction of roads and their $\mathrm{M} \& \mathrm{O}$ cost. We have assumed that the other services which are reduced do not produce externalities (positive or negative). Macro results are presented in Table 14.

Table 14: Macro results of road investments, funded by reduction of public expenditure

\begin{tabular}{||c||c|c|c|c|c|c||}
\hline \multicolumn{1}{|c|}{} & \multicolumn{3}{c|}{ Road (funded by reduction of other public } \\
expenditure )
\end{tabular}

${ }^{11}$ If fact, we could use the real exchange rate easily as our price index is exogenous in the model and is fixed at 1. 
The GDP effects are the same compared to simulation $2 \mathrm{~d}$ since the externalities are the same. However, for the households' we note weaker positive effects on equivalent variation in all the countries. The biggest reductions between the scenario $2 \mathrm{~d}$ and $2 \mathrm{a}$ are found for Cameroon going from $1.12 \%$ to $0.38 \%$ and for Senegal going from $1.0 \%$ to $0.5 \%$. The other countries experience only slight decreases of the positive effect. Given the reduction in public services, a downward pressure on labour versus the previous simulation takes place and this reduces the positive effect on the wage in four countries and reverses the positive effect to a negative effect in Benin and Senegal. An interesting aspect of this simulation compared to the previous simulation and the baseline case is that in all countries the firms are clear winners compared to households. This situation also produced a positive effect on private investment which increases in all countries. Tanzania and Cameroon experience the largest increases in private investment with increases of $2.51 \%$ and $2.02 \%$ respectively.

We also note that the effect on the nominal exchange rate is not consistent with an appreciation in three countries (Mali, Senegal and Cameroon) and depreciation in the three other (Benin, Tanzania and Uganda). This is a consequence of the import and export structure in the different countries. The sectorial effects are presented in Table 15.

Table 15: Sectoral results for Road investments, Import duties funded

\begin{tabular}{|c|c|c|c|c|c|c|c|}
\hline \multirow[b]{2}{*}{ Variables } & \multirow[b]{2}{*}{ branches } & \multicolumn{6}{|c|}{ Road (reduction of other public expenditure) } \\
\hline & & Benin & Mali & Senegal & Tanzania & Uganda & Cameroon \\
\hline \multirow{7}{*}{$\begin{array}{c}V a \\
\text { (Value } \\
\text { added or } \\
\text { output) }\end{array}$} & Crop agriculture & 1.03 & 0.92 & 0.95 & 0.83 & 0.22 & 1.34 \\
\hline & Export agriculture & 1.50 & 1.37 & 1.91 & 1.25 & 0.36 & 1.53 \\
\hline & Mining and Gas & & 1.54 & & 1.52 & 0.09 & 1.59 \\
\hline & Industries & 1.75 & 0.83 & 1.75 & 0.82 & 0.35 & 1.18 \\
\hline & Construction & & 2.25 & 3.32 & 2.05 & 1.66 & 8.70 \\
\hline & Private Services & 1.24 & 0.5 & 1.19 & 0.61 & -0.01 & 0.72 \\
\hline & Public services & -7.05 & -1.43 & -3.46 & -2.06 & -2.20 & -4.25 \\
\hline Variables & branches & & & & & & \\
\hline \multirow{5}{*}{$\begin{array}{c}p q \\
\text { (Market } \\
\text { prices) }\end{array}$} & Crop agriculture & -0.02 & -0.12 & -0.24 & -0.30 & -0.11 & -0.36 \\
\hline & Export agriculture & 0.03 & -0.59 & -0.64 & -0.70 & -0.20 & -0.37 \\
\hline & Mining and Gas & & -0.97 & & -0.05 & 0.18 & -0.28 \\
\hline & Industries & 0.89 & -0.36 & -0.73 & 0.19 & 0.07 & 0.10 \\
\hline & Construction & & 0.03 & 5.71 & 0.94 & 0.45 & 0.16 \\
\hline
\end{tabular}




\begin{tabular}{||c||c||c|c|c|c|c|c||} 
& Private Services & -0.37 & 0.38 & -0.51 & 0.42 & -0.02 & 0.10 \\
& Public services & -2.19 & 0.4 & -0.41 & 0.51 & 0.05 & 0.24 \\
\hline \hline Variables & branches & & & & & & \\
\hline \hline \multirow{4}{r}{} & Crop agriculture & 0.98 & 0.8 & 0.96 & 0.46 & 0.10 & 0.84 \\
& Export agriculture & 1.43 & 0.71 & 1.06 & 0.38 & 0.14 & 0.61 \\
(rental rate & Mining and Gas & & 0.55 & & -0.08 & -1.34 & 1.21 \\
of capital) & Industries & 3.26 & 1.24 & 0.47 & 0.91 & 0.54 & 1.67 \\
& Construction & & 2.53 & 16.23 & 3.40 & 2.51 & 9.51 \\
& Private Services & 1.34 & 0.97 & 0.72 & 1.02 & -0.08 & 0.84 \\
\hline \hline
\end{tabular}

When comparing these results with the baseline case, we note that all sectors increase their output and this is a direct result of road investment externalities. As we decrease other public services to fund the investment, this sector experience a strong decrease in all countries compared to the increase for the baseline situation. To analyze the sectorial effects we must keep in mind the road externality parameters presented in Table 4. The sectors benefiting the most are mining and gas, export agriculture and construction. Since we have other general equilibrium effects at play, it is not this ordering that dominate the final sectorial gains in each country. In fact, in Benin, we observe the strongest gains in the industrial sector. When excluding the construction sector that once again benefits from the increase in demand from the increase in public expenditure, we have the export agriculture (Senegal and Uganda) or mining and gas sectors (Mali, Tanzania and Cameroon) that benefit the most. The sectors benefiting the least are the crop agriculture or private services. We also observe a slight decrease in private services in Uganda which is the only sector outside public services in any country not increasing its output. The analysis of price effects reveals that the two agricultural prices decrease in all countries except for the export agriculture in Benin with a very slight increase of $0.03 \%$. The export agriculture decreases more than the crop agriculture in all countries except Benin. The construction prices increase from the demand pressure originating from the increase in investment but other prices do not follow specific trends. Given the positive externality effects, most rental rates of capital increase in all countries with the only exception for the rental rate of capital in mining and gas for Tanzania (-0.08\%) and Uganda (-1.34\%) and for the private services $(-0.08 \%)$ in Uganda.

\subsection{The investment in electricity infrastructure}


In this section, we analyse the investment on electricity infrastructure (set 3). The main characteristic versus the road infrastructure is that the main winners in terms of externalities are the industries, followed by the construction and mining and gas sectors. Moreover, the $\mathrm{M} \& \mathrm{O}$ costs of electricity infrastructure versus road infrastructure are 7\% higher. Hence, higher funding is required to sustain this investment compared to the road infrastructures.

\subsubsection{Investment funded by the value added tax}

The first funding option analyzed is the value added tax (3b). This funding option was also used for the non productive investment. We present the macro results in Table 16.

Table 16: Macro results of electricity investments, funded by VAT

\begin{tabular}{|c|c|c|c|c|c|c|c|}
\hline \multirow[b]{2}{*}{ Variables } & \multirow[b]{2}{*}{ Definition } & \multicolumn{6}{|c|}{ Electricity (VAT funded) } \\
\hline & & Benin & Mali & Senegal & Tanzania & Uganda & Cameroon \\
\hline$Y m$ & Aggregate household income & 0,70 & 0,59 & 0,91 & 0,49 & 0,16 & 0,90 \\
\hline$E \boldsymbol{V}$ & Equivalent variation & 0,62 & 0,57 & 0,84 & 0,47 & 0,16 & 0,83 \\
\hline$s$ & Wage & 4,18 & 0,83 & 2,02 & 0,74 & 0,27 & 1,40 \\
\hline yg & Government income & 13,97 & 3,03 & 5,61 & 5,17 & 2,98 & 6,04 \\
\hline ye & Firms income & $-0,04$ & 0,56 & 0,41 & 0,69 & 0,06 & 0,10 \\
\hline$g$ & Total government expenditure & 10,77 & 1,56 & 4,84 & 3,17 & 2,24 & 6,54 \\
\hline It & Total private investment & 0,61 & 0,73 & 0,41 & 1,72 & 0,16 & 0,65 \\
\hline $\boldsymbol{e}$ & nominal exchange rate & 1,43 & 0,58 & 0,11 & 0,48 & 0,05 & 0,28 \\
\hline$G D P$ & $G D P$ & 0,66 & 0,63 & 0,83 & 0,72 & 0,18 & 0,80 \\
\hline
\end{tabular}

This is an interesting scenario to compare to the baseline case insofar as the funding mechanism used here is the same in the two cases. However, before moving to this comparative analysis, let us compare with the previous one ( $2 \mathrm{a}$ and $2 \mathrm{~d}$ ) for growth of GDP. Graph 2 is used to illustrate this comparative analysis.

Graph 2: GDP and EV changes for electricity investments, funded by VAT 


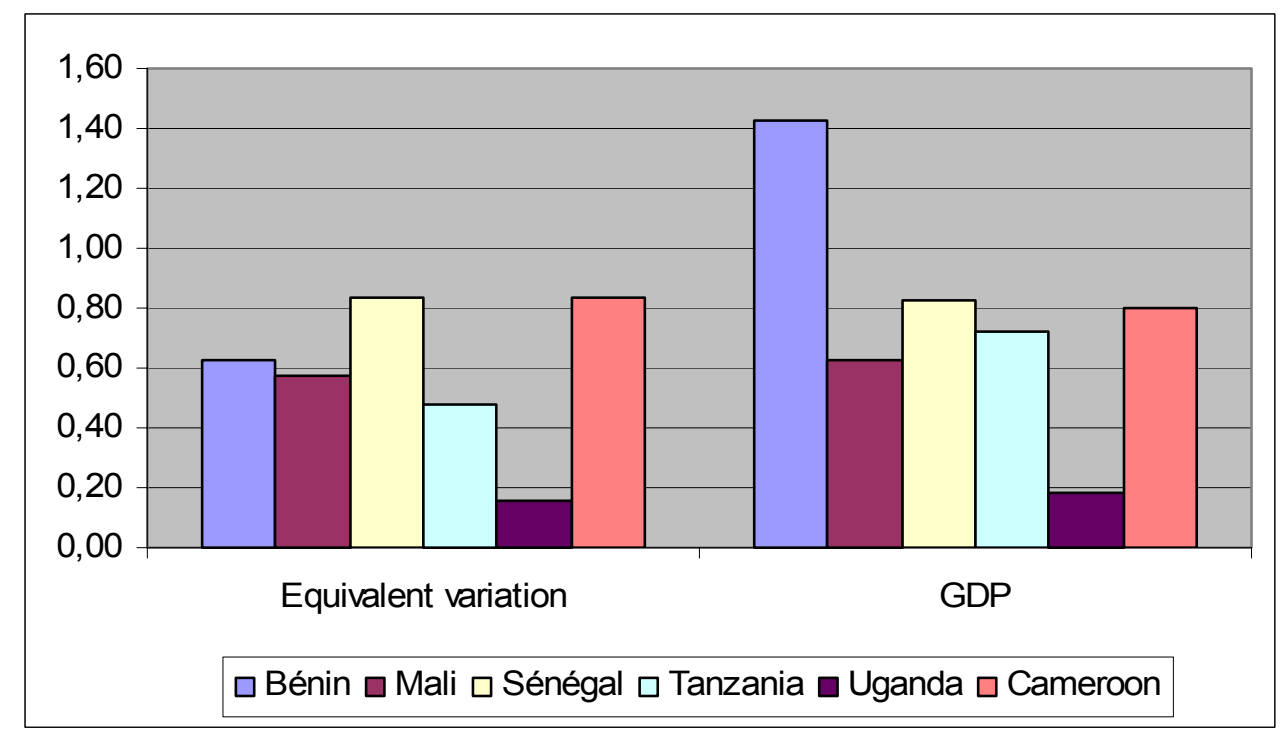

In this case, we have Senegal benefiting the most followed by Cameroon. The ranking is quit different and this comes from the structural differences of the economies and the externalities of electricity investments. As in the previous simulation analysed, the country difference are relatively small going from $+0.63 \%$ in Mali to a bigger growth of $0.83 \%$ in Senegal. In the case of road investment, the household gains were not systematically lower than the GDP growth. In fact, in three countries it was the opposite. In this case, the growth of GDP dominates the household gains with the exception of Cameroon and Senegal where the gap is very small (less then $0.03 \%$ in the two countries). Another difference is that households gain more than firms in five of six countries. The only exception is in Tanzania where firm's income increase by $0.69 \%$ compared to $0.49 \%$ for households. We even have a negative impact on firm's income for Benin. Since we have positive externalities all agents in all countries gain compared to the non externality option. Given the positive effect on firm's income in most countries and on households' income, we have an increase in private savings and consequently in total private investment for all countries. The strongest increase is in Tanzania $(+1.72 \%)$ and weakest in Senegal by $0.41 \%$. The eviction effect described in the non productive investment is completely eliminated by the externality effects. We did not get this clear effect in the two funding scenarios for the road investment as we get for electricity infrastructure.

The impact on the wage is similar in terms of intensity with the baseline (set 1) and for the ranking of countries. In some cases, the impact is larger here and in other cases the change in wage rate was larger for the non productive investment case. We still observe relatively large 
differences in wage rate changes going from the largest change for Benin with $+4.18 \%$ to weakest increase of $0.74 \%$ for Tanzania.

As for the exchange rate we observe depreciations in the nominal exchange rate, favouring an increase exports and reducing imports to clear the current account balance. The strongest effect on the nominal exchange rate is in Benin $(+1.43 \%)$ and the weakest is in Mali $(+0.63 \%)$. We present the sectorial effects for simulation $3 \mathrm{~b}$ in Table 17.

Table 17: Sectoral results for electricity investments, VAT funded

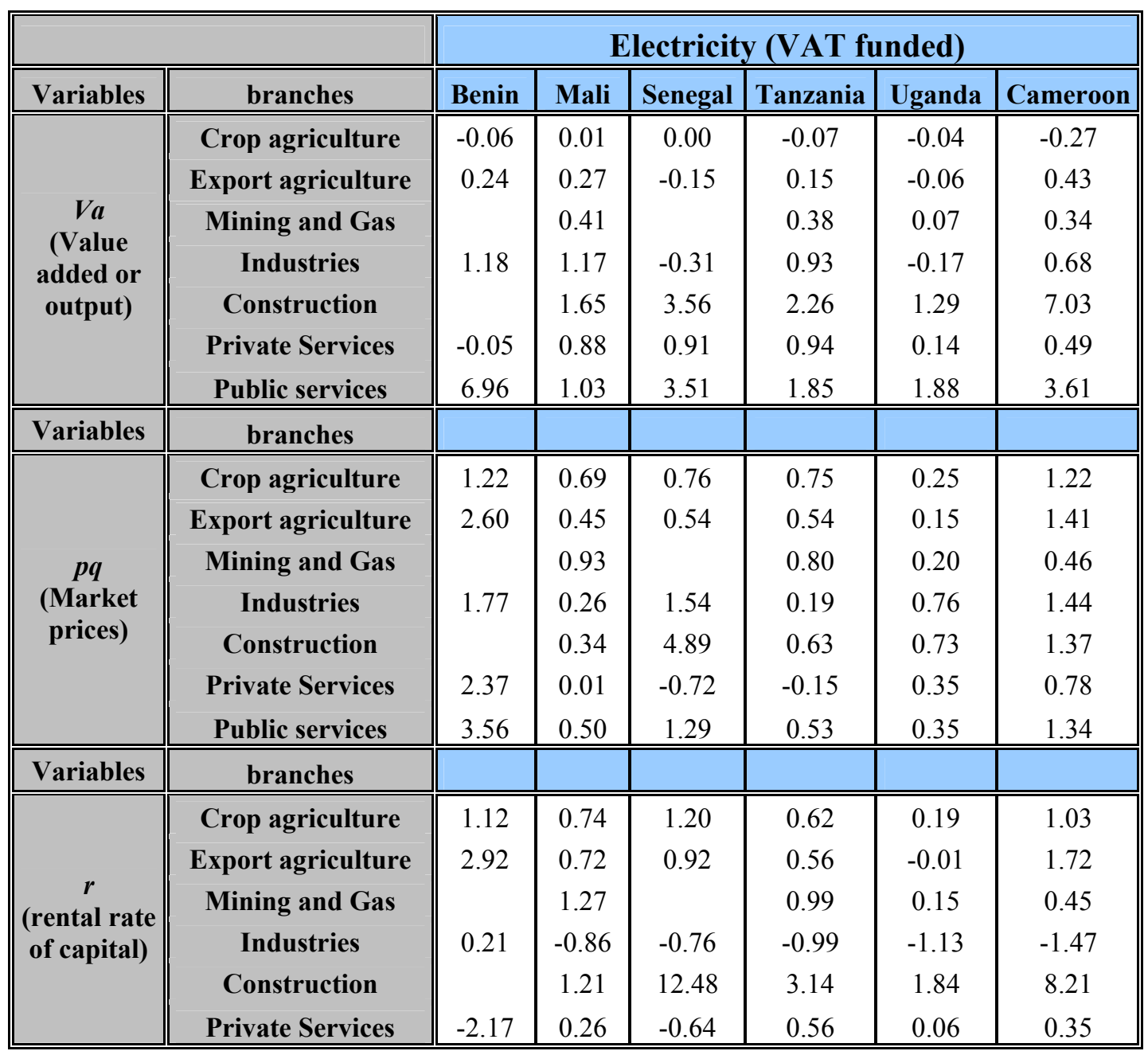

In light of these results, we can say that the elasticity of externalities do not play a dominating role in raking positive impact on the sectors in the different countries as the ranking has not changed from the baseline case. As in the previous simulation, we expected the construction sector to fair best as it benefits from two positive effects, namely the strong increase in demand and a favourable ranking in terms of externality of electricity investment. We do observe this in 
all countries except in Uganda where the public services are the biggest winner for this option but in this case it is the $\mathrm{M} \& \mathrm{O}$ cost increase that accounts for the large public service increase. It is also quit surprising that the industry sector in Senegal and in Uganda see their outputs decrease. This can be explained by the fact that in these two countries the VAT is much higher in the industry sector compared to other sector. It is also interesting but not surprising to see that the crop agriculture output decreases or is constant in all countries and the export agriculture increase slightly in Benin $(+0.24 \%)$ and in Cameroon $(+0.43 \%)$. This is explained by low electricity externalities for these sectors.

We observe that almost all market prices increase with the exception of private services in Senegal and Tanzania. These increases in market prices have reduced the positive effect generated by the increase in wage on the household welfare in all countries. Comparing the ranking of the market price effects across countries does not reveal any particular trend. When excluding the construction sector for the rental rate of capital analysis, we note relatively strong decreases in the rental rate of industry with the exception of Benin. Private services rental rate decreases in Benin and Senegal and all other rental rate of capital increase or remain almost constant. The largest increases are in the two agricultural sectors and mining and gas for all countries again when excluding the construction sector.

\subsubsection{Electricity investment funded by income tax}

In this section, we compare the second funding option for the electricity investments (3e). It is the first time we look at this household income tax funding option. We expected that this option will be least favourable to households compared to the firms at least in aggregate terms as the households will directly fund these investments through higher taxes. This is what partial equilibrium results would reveal. The general equilibrium effects can be different as the price and income effects are taken into account and in the VAT option, the consumers face higher consumer prices which also produces a negative effect on their welfare. The macro results are presented Table 18 .

Table 18: Macro results of electricity investments, funded by income tax

\begin{tabular}{||c||c||c|c|c|c|c|c||}
\hline \multirow{2}{*}{\multicolumn{1}{|c||}{ Dariables }} & \multicolumn{5}{c||}{ Electricity (Income tax funded) } \\
\cline { 2 - 9 } & Definition & Benin & Mali & Senegal & Tanzania & Uganda & Cameroon \\
\hline \hline $\boldsymbol{Y} \boldsymbol{m}$ & Aggregate household income & 0.70 & 0.61 & 0.90 & 0.50 & 0.16 & 0.99 \\
\hline $\boldsymbol{E} \boldsymbol{V}$ & Equivalent variation & 0.64 & 0.59 & 0.84 & 0.49 & 0.16 & 0.90 \\
\hline
\end{tabular}




\begin{tabular}{||c||c||c|c|c|c|c|c||}
$\boldsymbol{s}$ & Wage & 4.52 & 0.99 & 2.00 & 0.77 & 0.28 & 1.59 \\
\hline $\boldsymbol{y g}$ & Government income & 13.97 & 3.03 & 5.61 & 5.17 & 2.98 & 6.04 \\
\hline $\boldsymbol{y} \boldsymbol{e}$ & Firms income & -0.10 & 0.50 & 0.41 & 0.65 & 0.06 & -0.11 \\
\hline $\boldsymbol{g}$ & Total government expenditure & 10.77 & 1.56 & 4.84 & 3.17 & 2.24 & 6.54 \\
\hline $\boldsymbol{I} \boldsymbol{t}$ & Total private investment & 0.42 & 0.67 & 0.23 & 1.40 & -0.45 & 0.40 \\
\hline $\boldsymbol{e}$ & nominal exchange rate & -1.13 & 0.06 & -1.09 & -0.34 & -1.96 & 0.80 \\
\hline $\boldsymbol{G D P}$ & $\boldsymbol{G D P}$ & 0.67 & 0.63 & 0.83 & 0.72 & 0.18 & 0.80 \\
\hline
\end{tabular}

We focus this analysis by comparing the funding scenario (3e) with the VAT option presented previously (3b). Starting with the equivalent variation, the impact on the household welfare is almost identical to the VAT option in all countries. We only observe very small differences in four countries were the income tax option in more favourable by $0.02 \%$ in Benin, Mali, Tanzania and $0.07 \%$ more favourable in Cameroon. These differences are quit negligible. In terms of the impact on GDP, no differences are observed for all countries. The change in wage rate is stronger in all countries but Senegal where the effect is just slightly smaller compared to the VAT funding case. The effect on the income of firms is also quit similar although in this scenario we have a reversal of situation for Cameroon going from a positive effect $+0.1 \%$ to a negative effect of $-0.11 \%$.

It is interesting that the strongest effect on the macro variables is on the nominal exchange rate. We had all rates increasing (depreciating) and we now they are declining (appreciating) in four countries. The largest difference is in Uganda going from an increase of $0.05 \%$ to a decrease of $1.96 \%$. The other variable where we observe differences is for total investment in Uganda where it went from a positive effect $+0.16 \%$ to a decrease of $0.45 \%$. Overall, this funding option is almost identical to the VAT option with the biggest differences at the nominal exchange rates. Hence, the policy maker could choose either option without creating major differentiated impact at the macro level.

\subsection{The investment in telecom infrastructure}

For our final investment option, we analyze the telecom infrastructure investment. For this option, we analyse the import duties (4c) and foreign aid (4d) funding options. As shown in Table 4, presenting elasticities, the two services sector and the construction sector are the ones benefiting the most. These sectors are followed by the two agricultural sectors, followed by the industries and the mining and gas sectors. 


\subsubsection{Investment funded by foreign aid}

We will focus our comparative analysis on the baseline and road investment as these investment options were also analysed for the foreign aid funding option. The macro results are presented in Table 19.

Table 19: Macro results of telecom investments, funded by foreign aid

\begin{tabular}{|c|c|c|c|c|c|c|c|}
\hline \multirow[b]{2}{*}{ Variables } & \multirow[b]{2}{*}{ Definition } & \multicolumn{6}{|c|}{ Telecom (funded by foreign aid ) } \\
\hline & & Benin & Mali & Senegal & Tanzania & Uganda & Cameroon \\
\hline$Y m$ & Aggregate household income & 0.49 & 0.50 & 0.65 & 0.32 & 0.14 & 0.82 \\
\hline$E V$ & Equivalent variation & 0.49 & 0.50 & 0.64 & 0.33 & 0.17 & 0.85 \\
\hline$s$ & Wage & 4.15 & 1.26 & 1.55 & 0.51 & 0.32 & 1.50 \\
\hline$y g$ & Government income & 12.79 & 2.77 & 5.13 & 4.73 & 2.73 & 5.53 \\
\hline ye & Firms income & -0.25 & 0.15 & 0.19 & 0.37 & -0.11 & -0.83 \\
\hline$g$ & Total government expenditure & 8.85 & 1.28 & 3.98 & 2.61 & 1.84 & 5.38 \\
\hline It & Total private investment & -0.05 & 0.26 & -0.45 & 0.30 & -3.46 & -0.76 \\
\hline$e$ & nominal exchange rate & -4.96 & -1.39 & -4.27 & -1.87 & -11.38 & -5.51 \\
\hline GDP & GDP & 0.44 & 0.44 & 0.55 & 0.45 & 0.13 & 0.42 \\
\hline
\end{tabular}

This simulation provides an interesting result insofar as the variation of GDP is almost identical in each country. Taking into account the lower scale of the Uganda simulation, we would have results ranging from the low $0.42 \%$ increase in Cameroon to a high of $0.55 \%$ in Senegal. This is the lowest country differences in all simulations we have analyzed until now. As for the impact on the households, the effects are also quit similar but more differentiated compared to the GDP variations. The only exception on these similar results is for Cameroon where the positive effect on households is twice as large at the GDP increase.

Graph 3: GDP and EV changes for telecom investments, funded by foreign aid

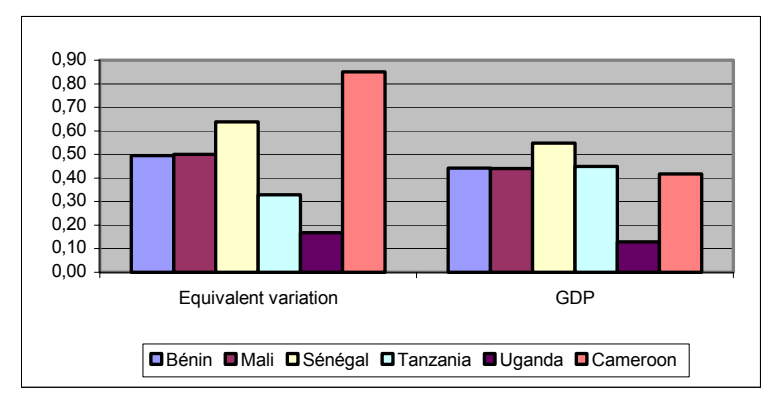

As in other simulations, the wage rate change is stronger in Benin $(4.15 \%)$ and weakest in Tanzania $(0.51 \%)$. For all countries except Tanzania, the impact on households' welfare is more 
favourable compared to the impact on firms. As for the road investment funded by foreign aid, we observed an important currency appreciation (or a reduction in the nominal exchange rate) in all countries. In fact, the impact on the nominal exchange rate is almost the same in four countries for the two types of investments. Differences emerge with slightly lower effect for Mali (-1.39\% compared to $-2.25 \%$ for road investment) and for Cameroon (-5.51\% compared to $-6.31 \%$ for road investment).

Moving to the sectorial effects, presented in Table 20 below, we note stronger differences between countries as oppose to the impact on macro variables. In fact, the results are completely different from one country to the other. Most countries have two sectors that decrease their production with the exception of Tanzania. Moreover, the ranking of the effects is also completely different between countries. Hence, we cannot talk about a specific trend at the sectorial level for this scenario.

Table 20: Sectoral results for telecom investments, funded by foreign aid

\begin{tabular}{|c|c|c|c|c|c|c|c|}
\hline \multirow[b]{2}{*}{ Variables } & \multirow[b]{2}{*}{ branches } & \multicolumn{6}{|c|}{ Telecom (Foreign aid) } \\
\hline & & Benin & Mali & Senegal & Tanzania & Uganda & Cameroon \\
\hline \multirow{7}{*}{$\begin{array}{c}V a \\
\text { (Value } \\
\text { added or } \\
\text { output) }\end{array}$} & Crop agriculture & 0.26 & 0.28 & 0.37 & 0.20 & 0.08 & -0.43 \\
\hline & Export agriculture & 0.34 & 0.37 & -0.22 & 0.04 & -0.40 & -0.07 \\
\hline & Mining and Gas & & -0.06 & & 0.29 & 0.92 & 0.04 \\
\hline & Industries & -1.64 & 0.39 & -0.53 & 0.44 & -1.33 & 0.18 \\
\hline & Construction & & 1.59 & 2.56 & 0.93 & 1.92 & 7.75 \\
\hline & Private Services & -0.48 & 0.46 & 0.38 & 0.51 & 0.04 & 0.03 \\
\hline & Public services & 2.62 & 0.79 & 3.59 & 1.70 & 3.65 & 3.17 \\
\hline Variables & branches & & & & & & \\
\hline \multirow{7}{*}{$\begin{array}{c}p q \\
\text { (Market } \\
\text { prices) }\end{array}$} & Crop agriculture & -0.30 & 0.19 & -0.78 & 0.07 & -0.15 & 0.68 \\
\hline & Export agriculture & -0.55 & -0.23 & -0.66 & 0.07 & -0.46 & 0.80 \\
\hline & Mining and Gas & & -0.34 & & -1.06 & -9.60 & -5.42 \\
\hline & Industries & 0.51 & -0.83 & -1.79 & -0.51 & -4.39 & -0.68 \\
\hline & Construction & & -0.04 & 5.41 & -0.03 & -1.52 & -0.17 \\
\hline & Private Services & -0.56 & -0.03 & -1.26 & -0.31 & -1.82 & 0.10 \\
\hline & Public services & 6.07 & 0.47 & 0.38 & 0.23 & -1.74 & 0.93 \\
\hline Variables & branches & & & & & & \\
\hline \multirow{5}{*}{$\begin{array}{c}r \\
\text { (rental rate } \\
\text { of capital) }\end{array}$} & Crop agriculture & 0.04 & 0.55 & 1.68 & 0.29 & 0.28 & 0.48 \\
\hline & Export agriculture & -0.38 & -0.18 & -0.19 & -0.14 & -0.76 & 0.44 \\
\hline & Mining and Gas & & -2.09 & & 0.74 & 4.32 & -6.75 \\
\hline & Industries & 5.60 & 1.59 & -1.77 & 0.84 & -2.67 & 1.25 \\
\hline & Construction & & 2.37 & 15.80 & 0.80 & 3.23 & 9.90 \\
\hline
\end{tabular}


When looking at the market prices, we observe that most prices decrease in all countries. This is a contrast compared to the options where either taxes where used to fund the investment. The ranking of price effects between countries is very different. In Benin, the biggest decrease is in private services, in Mali and Senegal it is for the industry sector, in Tanzania, Cameroon and Uganda, it is the mining and gas sector. Both agricultural prices decrease in Benin, Senegal and Uganda, both increase in Cameroon and Tanzania. However, in Mali the crop agriculture price increases and the export agriculture price decreases. The biggest price effects are felt in Uganda, but this is linked to the same problem of the large size of foreign aid that is required which puts strong pressure on the exchange rate.

Finally the rental rate of capital follows the same trend as other sectoral variable for this simulation insofar is no specific trend is observed in terms of the ranking of the effects. However, we note that all crop agriculture rental rate increase and five out of six export agriculture prices decrease. The only exception is observed in Cameroon with an increase of $0.44 \%$. As in other simulations, we have a very strong increase in the rental rate of capital for the construction sector in Senegal at $15.8 \%$ and in Cameroon at 9.9\%. The changes in rental rates of capital in Tanzania are all below $1 \%$ with the highest increase in industries at $0.84 \%$.

\subsubsection{Investment funded by import duties}

Our final simulation analyzed is the investment in telecom infrastructure funded by import duties (4c) which we can compare with the baseline scenario funded by import duties.

Table 21: Macro results of telecom investments, funded by import duties

\begin{tabular}{||c||c||c|c|c|c|c|c||}
\hline \hline \multicolumn{1}{|c||}{} & \multicolumn{5}{c||}{ Telecom (Import duties funded) } \\
\cline { 4 - 8 } Variables & Definition & Benin & Mali & Senegal & Tanzania & Uganda & Cameroon \\
\hline \hline $\boldsymbol{Y} \boldsymbol{m}$ & \multirow{2}{*}{ Aggregate household income } & 0.48 & 0.46 & 0.62 & 0.31 & 0.12 & 0.60 \\
\hline $\boldsymbol{E} \boldsymbol{V}$ & Equivalent variation & 0.46 & 0.45 & 0.58 & 0.31 & 0.12 & 0.55 \\
\hline $\boldsymbol{s}$ & Wage & 3.88 & 0.94 & 1.45 & 0.49 & 0.21 & 1.01 \\
\hline $\boldsymbol{y} \boldsymbol{g}$ & Government income & 12.79 & 2.77 & 5.13 & 4.73 & 2.73 & 5.53 \\
\hline $\boldsymbol{y} \boldsymbol{e}$ & Firms income & -0.21 & 0.26 & 0.22 & 0.40 & 0.03 & -0.27 \\
\hline $\boldsymbol{g}$ & Total government expenditure & 8.85 & 1.28 & 3.98 & 2.61 & 1.84 & 5.38 \\
\hline $\boldsymbol{I t}$ & Total private investment & 0.24 & 0.38 & 0.05 & 0.73 & -0.44 & -0.07 \\
\hline
\end{tabular}




\begin{tabular}{||c||c||c|c|c|c|c|c||}
$\boldsymbol{e}$ & nominal exchange rate & -0.95 & -0.32 & -1.10 & -0.64 & -1.75 & -1.55 \\
\hline $\boldsymbol{G D P}$ & $\boldsymbol{G D P}$ & 0.44 & 0.44 & 0.55 & 0.45 & 0.13 & 0.41 \\
\hline
\end{tabular}

Like in the previous simulation (4d), the impact on GDP is almost identical between countries and compared to the last two simulations. Comparing this simulation to simulation $4 \mathrm{D}$, the households improve their situation versus the baseline scenario (1b) with the largest effect in Senegal followed by Cameroon. This is different from the previous case (4d) where Cameroon came first in ranking the effects. Moreover, the effect is still positive but stronger for the households in all country when funded by foreign aid. The ranking of other countries is the same as for the foreign aid option (4d).

Graph 4: GDP and EV changes for telecom investments, funded by import duties

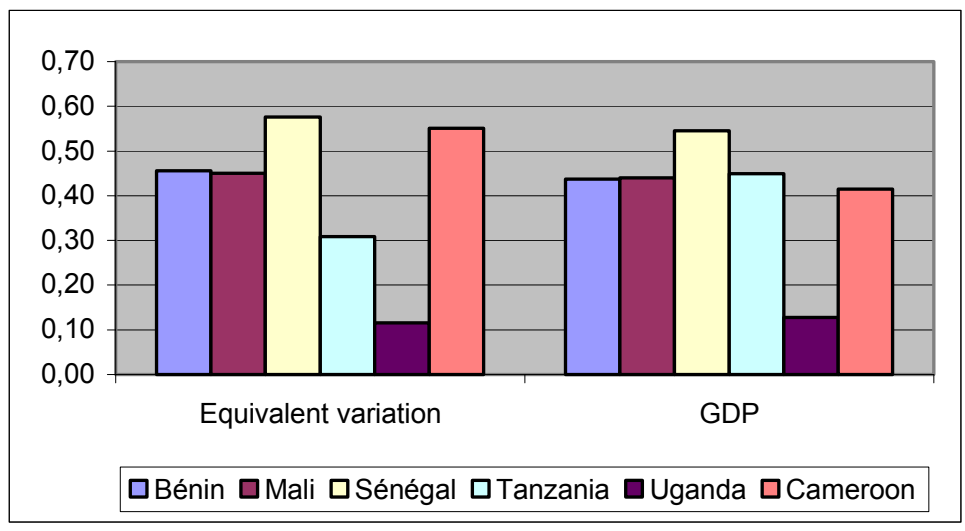

The impact on the wage rate is weaker compared to $4 \mathrm{~d}$ and the ranking remains the same between the countries. The same situation is observed for firms and for households, namely that the situation is improved versus the foreign aid funded option in all countries. The households are winner when compared to firms in all country but Tanzania. In that foreign aid funded option, investment increased slightly in only two countries (Mali $+0.26 \%$ and Tanzania $(0.3 \%)$. However, for this funding option, we observe an increase in investment in four countries and strong decreases in Uganda and Cameroon. For simulation 4d, investment was not as negative for these two countries. Finally, in this case, the nominal exchange rate is not under as much pressure as in the previous case with all changes being below $2 \%$. The strongest appreciation of the exchange rate is in Uganda $-1.75 \%$ and Cameroon at $-1.55 \%$. We observe a decrease for the nominal exchange rate in all countries.

\subsection{General comparative analysis}


To summarize our comparative analysis we can say that most simulations analysed produce similar effects on some macro variables in some cases such as the telecom investment in terms of qualitative and quantitative effects. However, these similar cases were more an exception than the rule and for the road and electricity investment we observe relatively large differences quantitatively and some qualitative differences at the macro level. An interesting element is that the sectorial analysis has revealed strong differences between the countries and between the types of investments performed. The differences were larger than expected as all models had the exact same, behavioural equations and elasticities. The only differences between the models concerned the structure of the economies and this seems to have played an important role in the final results. The result also showed that the general equilibrium effects are important to take into account as the price effects often dominate the income effect in terms of change in household welfare. We also have cases were firms were winners compared to households and others when it was the opposite. Tanzania seems to come out most often as an exception on this front when comparing countries.

\section{Conclusion}

The analysis has allowed us to analyse the impact of scaling up infrastructure investment in six African countries with different economic structures as was described in the paper. The different economic structures contribute to producing diversified results for the same type of investment funded by the same sources with the same archetype model. The structure of the economy where these policies will be applied needs to be taken into account. Our analysis also shows that even with a relatively aggregated production structure in the models, we do not have such clear-cut sector that can be classified as tradable and non tradable sector. One often finds in the literature, production sector such as export agriculture classified in the tradable, but our figures reveal that most of the production of these sectors are destined to local industries that will eventually export a portion of the transformed product. We also have a construction sector in Tanzania that is tradable where it is non tradable in other countries. This is certainly at the source of the specific results in this country.

Another important conclusion is that funding investment through foreign aid if the current account needs to be balanced produces the strongest sectorial effects since strong price and nominal exchange rate adjustments are needed to clear the current account balance. The sectoral 
effects are strongly influenced by the structure of imports and exports observed in the different country as well as the size in the inflow of funds required to finance the public infrastructure. It is therefore important to analyze such reforms in a modeling context as disaggregated as possible and to fully take into account the structural characteristics of the country. The other important structural characteristic is the capital/labor ratio in the different productive sectors. This plays an important role in determining the winners and losers as relative effects on factor payments are strongly related to the capital/labor ratios.

Our results show that scaling up infrastructure does not always produce a Dutch disease effect. Scaling up foreign aid to fund infrastructure produced the Dutch disease in our four types of investment ${ }^{12}$. However, for the foreign aid scenarios, the intensity of the Dutch disease varies from one type of investment to the other and between countries. It is not clear that tradable sectors will always be the most favoured by investments in infrastructure as this is dependent on the type of investments. Another important result is that the size of the negative social impact of the Dutch disease will depend on degree of labour intensity in the tradable sectors. The other important conclusion is that for our scenarios with appreciation of the exchange rate (Dutch disease symptom), we observe an increase in the welfare of aggregate households measured by the equivalent variation. This comes from the growth effect of the positive production externalities of infrastructure investment. This positive growth effect compensates other negative effects among which the Dutch disease in included.

An important caveat should be added to our findings. The characteristics of the different sectors in terms of export behaviour and preferences between imports and locally produced goods in the different countries are likely to be quit different from one country to the other. We have assumed for comparative basis that these were the same. Relaxing this hypothesis would certainly have amplified the country differences we have observed in our models. A good illustration for this is preferences of national consumers for imported and locally produced rice. In certain countries, the consumers have a strong preference for Asian produced rice (Senegal) and in others they prefer locally produced rice (Mali) for historical reasons ${ }^{13}$. On the export side, a landlocked country will have smaller export CET elasticity compared a costal country with good port and

\footnotetext{
12 In fact, we only reported the results for two types of investments but the results hold for all types of productive investments.

13 Senegal was used by France to absorb excess production of Indochina riche production during colonial period.
} 
airport infrastructure. These differences could be quit large. It is much more difficult for a landlocked country to export perishable agricultural products compared to a costal country near large markets. Adding these assumptions into the analysis would only have enriched our conclusions we have stated here and would reinforce the caveat of using aggregated models which distinguishing only two or three sectors such as tradable and non tradable sectors. On the other hand, the comparative analysis would have been more difficult with these differences in the models.

In a subsequent paper, we will extend this analysis to investigate distribution impact of scalingup of infrastructure for countries where micro household database will be available.

\section{References}

Aschauer, D. A., (1989), "Is Public Investment Productive", Journal of Monetary Economics, Vol. 23, pp. 177-200.

Adam, C. and D. Bevan (2006), "Aid and the Supply Side: Public Investment, Export Performance and Dutch Disease in Low Income Countries," World Bank Economic Review, Vol. 20(2), pp. 261-290.

Anderson, J. E. and W. Martin (1998), Evaluating Public Expenditures When Governments Must Rely on Distortionary Taxation, mimeo, Boston College World Bank.

Armington P. S., 1969 - "A Theory of Demand for Products Distinguished by Place of Production”, IMF Staff Paper n ${ }^{\circ} 16$, pp. 159-176.

Bajo-Rubio, O. and S. Sosvilla-Rivero (1993), "Does Public Capital Affect Private Sector Performance?" Economic Modelling, Vol. 10, n 3, pp. 179-185.

Barro, R. J. (1991), "Economic Growth in a Cross Section of Countries", Quarterly Journal of Economics, 106 (2), May: 407-43.

Barro, R. J. (2001), "Education and Economic Growth", in Helliwell (2001).

Bils, M. and P. J. Klenow (2000), "Does Schooling Cause Growth?", American Economic Review, 90 (5): 1160 - 1183.

Davies, J. (2003) Empirical Evidence on Human Capital Externalities, Working Paper no. 20035, Economic Policy Research Institute, University of Western Ontario, London.

Decaluwé B., A. Martens and L. Savard, (2001), «La Politique Economique du Développement et les modèles d'équilibre général calculable », Association des Universités Francophones AUFPresse de l'Université de Montréal, Montréal. PP. 1-509. 
Dessus, S. and R. Herrera, (1996), « Le rôle du Capital Public dans la Croissance des Pays en Développement au cours des Années 80 », Document de Travail de 1'OCDE, nº 115, Paris.

Direction Nationale de la Statistique et de l'Informatique-DNSI, (2007), 'Les comptes économiques', Bamako, Mali.

Dumont, J.C. and S. Mesplé-Somps, (2000), "The Impact of Public Infrastructure on Competitiveness and Growth: A CGE Analysis Applied to Senegal", Mimeo, CREFA, Université Laval, Québec.

Fay, M. and T. Yepes, (2003), "Investing in Infrastructure: What is Needed from 2000-2010?", World Bank Policy Research Working Paper n³102, World Bank, Washington.

Foster, M. and T. Killick (2006), "What Would Doubling Aid Do for Macroeconomic Management in Africa?" Working Paper no. 264, Oversees Development Institute, London.

Fougère, M. and M. Merette (1999) "Population Ageing and Economic Growth in Seven OECD Countries", Economic Modelling, 16: 411-427.

Jung, H.S. and E. Thorbecke (2003) "The Impact of Public Education Expenditure on Human Capital, Growth and Poverty in Tanzania and Zambia: A General Equilibrium Approach". Journal of Policy Modelling, 25: 701:725.

Gramlich, E. (1994), "Infrastructure Investment: A Review Essay”, Journal of Economic Literature, Vol. 32, nº 3, pp. 1176-1196.

Gupta, S. R. Powell and Y. Yang, (2006), 'Macroeconomic Challenges of Scaling Up Aid to Africa: a Checklist for Practioners, Washington, D.C. IMF.

McKinley, T. (2005), "Why is the Dutch Disease Always a Disease? The Macroeconomic Consequences of Scaling Up ODA", Working Paper no. 10, International Poverty Centre, Brasilia.

Munnell, A. H. (1990), "Why Has Productivity Declined? Productivity and Public Investment" New England Economic Review, January/February, pp. 3-22..

Savard, L. and E. Adjovi (1998), «Externalités de la santé et de l'éducation et bien-être : Un MEGC appliqué au Bénin. », l'Actualité Économique, Vol. 74, nº 3, pp. 523-560.

Voyvoda, E, and Yeldan, E., (2005), IMF Programs, Fiscal Policy and Growth: An Investigation of Macroeconomic Alternatives in an OLG Model of Growth for Turkey. Comparative Economic Studies, 47(1): 41-79

Yeaple, S. R., and S. S. Golub (2007) International Productivity Differences, Infrastructure, and Comparative Advantage, Review of International Economics, 15(2); 223-242 